\title{
Contemporary Religious Fundamentalism
}

\author{
Dr. Uma S. Sharma ${ }^{1}$
}

Keywords: Positive, Negative, and Thinking.

Though living side by side for centuries, the sentiments Hindus and Muslims have never adequately understood or trusted one another, and killings, partition and wars have resulted. Thus a fresh look at the religious fundamentalism is not hard to justify. Not that India-Pakistan and India-Bangladesh relations can be equated with the. Hindu- members in Pakistan are negligible, and Muslim participation in India's conflicts with Pakistan has always been more than nominal. But the two subjects, how the neighboring nations get along and how the neighboring communities do, are not unconnected.

Passions, however, overtake our understanding. We take sides before we have grasped what's happened and is happening. We are merely more polarized, not better informed, after we have read and talked of issues such as Shah Bono or of Babri Masjid Ram Janmbhoomi. Our religious fundamentalism and the consequential communal riots have many dimensions, including the commercial, the political and the criminal, but it is undeniable that they fuel polarization and also feed on it.

Religious fundamentalism in the South Asian region has assumed serious proportions in the last few decades. Sri Lanka, India Pakistan and to some extent Bangladesh face this problem. It is therefore necessary to examine this problem in detail.

The question that crops up is what is religious fundamentalism? Why does it get aggravated so as to express itself violently. At the same time the difference between ethnicity and religious fundamentalism too should be clarified. Thus we first come to the issue of ethnicity. Ethnicity, anthropologists and Sociologists maintain, is a feeling of primordial identity with one's social religious, linguistic or cultural group. A writer in New Left Review puts it as:

Hindu-Muslim encounter. Both communities live in all three countries, even if

"All through the twentieth century the significance of social life in setting patterns of political action has been extensive and usually unpredicted. Neither its treatment by the nineteenth century 'rationalist' as a retrograde piece of barbarism not its biological racial explanations by their 'romantic' foes stood well the test of further experience."

\footnotetext{
${ }^{1}$ Assistant Professor, Nalini Arts College, Vallabh Vidyanagar
} 


\section{Contemporary Religious Fundamentalism}

Thus ethnicity in the changing society, a society where the inter- group dynamics and inter group balance of power and changing, becomes much more than a primordial feeling. South East Asia is characterized by rich ethnic diversity and also witnesses large scale ethnic violence. The ethnic problem in Sri Lanka is an example. India too has its own share of ethnic conflict. The Nagas, the Mizos, the Assamese, the Bodes, and at the Gorkhas have been fighting for their ethnic demands. Pakistan too has its own share of ethnic diversity among the Sindhis, Baluchis , Pathans, Punjabis and Mohajirs along with the Hindus, Muslims and the Christians.

The Hindu Muslims problem does not fall strictly speaking within the ethnic category. The Hindus and the Muslims, from on region are from the same ethnic stock. But the present conditions are so complex and rapidly changing that ethnic and religious category, like caste categories get confused. Broadlly speaking the religious category does transcend the ethnic category. However, this does not mean that Hindus and Muslims would never unite on ethnic issues. For example, Tamil Hindus and Muslims might react together on the language issues.

A similar possibility exists regarding Kerala and Kashmir. Thus, the regional identities on certain occasions assume greater importance than their religious identity. However, there is much greater possibility of the religious identity assuming more serious proportions. Communal conflict, too, like ethnic conflict in a society in transition is basically causes by renogotiation of inter-communal status. Throwing light on this issue, Ashgar Ali Engineer observes:

"The Muslims in the post independence period, if not earlier, were a disadvantaged group, and are even now getting increasingly marginalized. In a ballot-box oriented set-up, a large minority like the Muslims has its own political weight. This causes where politicians are tempted to resort to caste and communal appeal. All marginalized groups, including the backwards and the Dalits, want to exploit theist voting power to renegotiate their status and these pressures cause their own problems."

The ethnic imbalance caused by migration on large scale in a developing economy like India, creates tense situations that on occasions explode into violence in the form of communal riots. But, on closer examination the issue would be found to be more of economic in nature, wile we believe that it is fundamentally an ethnic conflict.

Modern capitalist development has led to the aggravating of Ethnic and religious conflict. Thus it would be wrong to look for the roots of the problem in medieval period. Though, during that period there was strong religious and ethnic prejudice, the communal of fundamentalism did not exist. Differentiating between the terms being religious and religious fundamentalism, Ashgar Ali Engineer clarifies:

The former are accentuated by religious and metaphysical dogmas while the latter are generated by political and economic issues.

The capitalist from of economic development is uneven and aggravates exploitation and injustice. In a capitalist development certain communities and ethnic groups benefit disproportionately and 


\section{Contemporary Religious Fundamentalism}

others lose disproportionately. The colonization led to marked transition in the socio-economic structure and consequently the shift benefited the Hindus and harmed the political, social and economic interests of the Muslims. The reason for this can be attributed to the fact that the Muslim ruling class were mainly feudal and could not adjust to the shift in the socio economic structure, consequently did not take to industrial capitalism, which the Hindu did. Unlike India, Pakistan, even today maintains a largely feudal structure, and consequently industrial capitalism has not struck deep roots. This could be the chief reason for democracy not getting strongly rooted in the nation. In India too, the Muslims were largely left out of the process of development and it is the Hindus who benefited from it. Focusing on the consequences of losing out of the process of development, Ashgar Ali Engineer remarks:

One hand, the community which loses out finds no incentive to modernize and clings much more severely to its primordial identity. On the other hand, this produces a reaction among other communities, especially the majority community. The minority community is perceived as 'fanatical' and highly 'communal' for stressing its primordial identity.

Another characteristic of capitalism is urbanization. A large mass from the countryside shifts to the cities in search of employment. This leads to increasing pressure on the cities that are already over burdened in terms of space and resources. Thus, the migrants add to the already existing large slums and congested localities. But off from the culture and community, they seek to compensate for this by clinging to religion more fastidiously. This inclination towards religiosity is shrewdly manipulated by the politicians for their vested political interests. The one man one vote system of democracy makes it a very potent instrument of winning elections, and most of the politicians exploit the religious sentiments for ensuring their victory in the electoral process.

Religion in India undoubtedly plays an important role, not only in the social but also in the political sphere. Religion, in fact, is all pervasive as far as India is concerned. It was believed that religion would play a progressively less significant role with the spread of scientific education and attaining of modern temperament. Unfortunately, even with independence this has not happened. Besides, being secular state, it requires that religion be confined to the four walls of the home and public life remain unclenched by it. This too has not happened. Rather, religion has acquired a greater role in public life after independence. Thus, it should be kept in mind that when religion is socially so pervasive it is bound to influence our political sphere. Politicians have not and will not stop exploiting religious sentiments for their vested interests.

A religion, in order to be humane and creative, has to be dialogic. It must enter into dialogue with other religions. It is basically a fundamentalist and monologist religion that provides sustenance to communalism. Fundamentalism provides no scope to dialogue. Harmony in society depends on an ongoing dialogue between various religions and cultures. It is therefore imminent in contemporary India to encourage the process of inter-religious dialogue.

Fundamentalism is a great threat to the plurality and diversity and to the very secular credentials of the country. We cannot remain united if the plurality and diversity are threatened. Thus, 


\section{Contemporary Religious Fundamentalism}

countering the rise of religious fundamentalism is the need to the hour of the contemporary society.

\section{REFERENCES :}

1. Soviet Theories of Ethnicity: The Case of a missing term, New Left Review No. 158

2. Ashgar Ali Engineer : Lifting the Veil Communal Violence and Communal Harmony in Contemporary India, Sangam Books, Bombay, 1995, p.

3. Ashgar Ali Engineer : Lifting the Veilf Communal Violence and Communal Harmony in Contemporary India, Sangam Books, Bombay, 1995, p. 